\title{
The hazardous waste location and routing problem: an application in Marmara Region in Turkey
}

\author{
Durdu Hakan Utku' ${ }^{1}$ (D) Serpil Erol ${ }^{2}$
}

Received: 1 December 2019 / Accepted: 23 January 2020 / Published online: 30 January 2020

(c) Springer Nature Switzerland AG 2020

\begin{abstract}
Hazardous waste management involves the collection, transportation, processing, recycling and disposal of industrial and domestic wastes. In this study, a single objective, multi-product mixed integer programming model for hazardous waste facility location and routing problem is developed for the hazardous waste management problem. The aim of the study is to locate hazardous waste treatment, recycling and disposal facilities to the designated candidate locations with the lowest cost and highest profit. With this, we try to ensure that the waste is transported between hazardous waste generation centers and these facilities with the minimum cost and maximum revenue. Unlike the studies in the literature, we constructed an enhanced model that take all the following properties into account: the location of hazardous waste treatment, recycling and disposal facilities; transportation of hazardous waste, hazardous recycled materials and hazardous waste residues between these facilities; cost, revenue, risk, capacity and technology compatibility. The model provides to decide the sorts of facilities which are needed by considering the type and amount of hazardous waste generated in determining where to locate these facilities. The model, also, determines which types of hazardous waste can be transported between the facilities. The developed model is applied to the Marmara Region with the real data provided by the Republic of Turkey Ministry of Environment and Urbanization. Accordingly, the results are evaluated and presented.
\end{abstract}

Keywords Hazardous waste $\cdot$ Supply chain · Facility location $\cdot$ Logistics $\cdot$ Integer programming

\section{Mathematics Subject Classification 90}

\section{JEL Classification C61}

\section{Introduction}

A hazardous waste is a substance or material which is harmful to people, materials and the environment. As is well known, any hazardous waste is characterized by degree of the flammability, reactivity, corrosivity and toxicity [1].

Waste management includes prevention of the generation of waste; the reduction of waste at source; reuse, separation by type, accumulation, collection, temporary storage, transportation, intermediate storage, recycling, recovery (including energy recovery), disposal, monitoring after disposal, control and supervision of wastes [2]. The methods of incineration, over ground/underground storage and solar energy detoxification are used for the disposal of hazardous wastes. For the disposal of waste residues, the landfilling, deep-well-injection and pouring into the sea are the commonly benefited methods [2, 3]. Recycling refers to any recovery process (for example, the reprocessing of organic materials) in which wastes are

Durdu Hakan Utku, dhutku@thk.edu.tr; Serpil Erol, serpiler@gazi.edu.tr | ${ }^{1}$ Department of Industrial Engineering, University of Turkish Aeronautical Association, Ankara, Turkey. ${ }^{2}$ Department of Industrial Engineering, Gazi University, Ankara, Turkey. 
recycled and converted into products, materials. Recovery stands for making wastes ready for a useful purpose to be substituted for the materials used [2]. In the strategic management of hazardous wastes, the risks associated with hazardous wastes, the balanced distribution of risks, and the costs that should be incurred in the management process are the criteria considered. The objective is to minimize the cost and risk and to make the most balanced allocation of the risk to the affected areas.

Risk is a measure of possible undesirable consequences of the release of hazardous materials during the handling, storage, transportation and disposal of hazardous wastes. Gionnakis [4] expressed the risk as the total amount of waste transported. Revelle et al. [5], Alumur and Kara [1] and Samanlioglu [6] expressed transportation risk as a function of the possible population that could be affected by the amount of hazardous waste transported and the waste transported along the road route. Glickman et al. [7], Liu et al. [8] and Saat et al. [9] used the risk models for transportation of hazardous materials by rail.

Equity is the fair distribution of the consequences of a political decision to all members of society [10]. Erkut [11], Mandell [12] and Romero et al. [13] modelled the equity using the Gini coefficient. Kang et al. [14] have minimized the risk of "value at risk" at a certain level of confidence and the risk of "the number of trips between two points of destination" at a certain level of confidence for determining appropriate routes. Garrido and Bronfman [15] provided the equity by using thresholds in constraints.

Zografos and Samara [16] introduced one of the combined approaches for the location of hazardous materials facilities and hazardous materials transportation routes. Revelle et al. [5] proposed a model for the location of storage facilities, the assignment of nuclear reactors to these facilities, and the identification of routes for the transport of nuclear waste. Stowers and Palekar [17] developed a single-objective model for a single waste that minimizes the risk and provides the facility location and routing decisions. List [18] has introduced a multiobjective model that considers emergency response teams, response time, risk, risk balance and cost. Cappanera et al. [19] proposed a heuristic approach based on the Lagrangian relaxation for hazardous facility location and routing problem. Emek and Kara [3] have developed a combined hazardous waste management model in which the disposal facility location, waste disposal method and waste flow structure are included. Boffey et al. [20] introduced a multi-objective model for the location of low-level waste disposal plants. Erkut et al. [21] developed a multi-criteria mixed integer programming facility location approach. Samanlioglu [6] put forward a model based on the location of hazardous waste treatment facilities, recycling facilities, and routing of the waste and waste residues between these plants; including an application in the Marmara region in Turkey. Jiang et al. [22] posited a model based on locating hazardous material treatment facilities and routing the hazardous materials with different transportation modes, which is applied in Northeast China. Meiyi et al. [23] have developed a model for the hazardous materials transportation scheduling problem, where transportation risks consist of time-dependent fuzzy random variables. Zhao and Verter [24] have offered a two-objective model to minimize the total cost and risk and determine the facility location of the used petroleum products, treatment facilities and disposal facilities, and to determine the optimal transportation routes. Zhao et al. [25] developed a multiobjective mixed integer programming model by using extended weighted Tchebycheff approximation and extended $\varepsilon$-constraint approximations for facility location and routing problem. Yilmaz et al. [26] developed a model in which the environmental impacts of the multiobjective hazardous waste facility location and routing problem, where the total cost and risk are minimized. Rabbani et al. [27] suggested an approach for the hazardous waste location and routing problem including incompatibility of the wastes. They uses Non-dominated Sorting Genetic Algorithm (NSGA-II), Multi-objective Particle Swarm Optimization and Monte Carlo Simulation in order to solve the existing problems. Rabbani et al. [28] proposed a multi objective stochastic industrial hazardous waste location and routing model by considering a multi period planning horizon and incorporating the inventory decisions into the model. They made use of Non-dominated Sorting Genetic Algorithm (NSGA-II) and Monte Carlo Simulation in their study. Karadag [29] introduced a model which determines locations and numbers of recycling, incineration, sterilization, interim storage and disposal facilities and how to transport different types of hazardous wastes and waste residues by using a profit oriented mixed integer programming model. Zhao and Ke [30] studied on a multi-objective explosive waste management model minimizing the cost and the risk while locating the collection centres, managing the inventory level for each collection centre and routing the explosive wastes from collection centres to the recycling centres. Table 1 summarizes the studies in the literature and the model in this study.

The hazardous waste management model proposed in this study is a single-objective model based on multiple waste types. The risk and equity are considered in the constraints of the hazardous waste management model that we developed. Cappanera et al. [19] used facility and transportation risks in the constraints by using thresholds. Although the cost criterion is used in most of models in the literature, recycling and energy recovery are only taken 
Table 1 Comparison of the studies in the literature with the proposed hazardous waste management model

\begin{tabular}{|c|c|c|c|c|c|c|c|c|c|c|c|c|c|c|c|}
\hline References & OF & $\mathrm{C}$ & $\mathrm{E}$ & $\mathrm{R}$ & $\mathrm{T}$ & ST & I & RV & W & $\mathrm{TC}$ & TM & Tour & WTF & WRF & WDF \\
\hline Zografos and Samara [16] & M & $\mathrm{Y}$ & $\mathrm{N}$ & Y & $\mathrm{Y}$ & $\mathrm{N}$ & $\mathrm{N}$ & $\mathrm{N}$ & M & $\mathrm{N}$ & $S$ & $\mathrm{~N}$ & $\mathrm{~N}$ & $\mathrm{~N}$ & $\mathrm{Y}$ \\
\hline Stowers and Palekar [17] & $\mathrm{S}$ & $\mathrm{N}$ & $\mathrm{N}$ & Y & $\mathrm{N}$ & $\mathrm{N}$ & $\mathrm{N}$ & $\mathrm{N}$ & $S$ & $\mathrm{~N}$ & $\mathrm{~S}$ & $\mathrm{~N}$ & N & $\mathrm{N}$ & $\mathrm{Y}$ \\
\hline List and Mirchandani [31] & M & $\mathrm{Y}$ & Y & Y & $\mathrm{N}$ & $\mathrm{N}$ & $\mathrm{N}$ & $\mathrm{N}$ & M & $\mathrm{N}$ & $\mathrm{S}$ & $\mathrm{N}$ & Y & $\mathrm{N}$ & $\mathrm{N}$ \\
\hline Current and Ratick [32] & $\mathrm{S}$ & $\mathrm{N}$ & Y & Y & $\mathrm{N}$ & $\mathrm{N}$ & $\mathrm{N}$ & $\mathrm{N}$ & M & $\mathrm{N}$ & $S$ & $\mathrm{~N}$ & $\mathrm{~N}$ & $\mathrm{~N}$ & Y \\
\hline Wyman and Kuby [33] & M & $\mathrm{Y}$ & Y & $\mathrm{Y}$ & $\mathrm{N}$ & $\mathrm{N}$ & $\mathrm{N}$ & $\mathrm{N}$ & $S$ & $\mathrm{Y}$ & $S$ & $\mathrm{~N}$ & $\mathrm{Y}$ & $\mathrm{N}$ & $\mathrm{N}$ \\
\hline Alidi [34] & M & $\mathrm{N}$ & $\mathrm{N}$ & $Y$ & $\mathrm{~N}$ & $\mathrm{~N}$ & $\mathrm{~N}$ & $\mathrm{E}$ & $S$ & $\mathrm{~N}$ & $S$ & $\mathrm{~N}$ & $\mathrm{~N}$ & $\mathrm{~N}$ & $\mathrm{~N}$ \\
\hline Giannikos [4] & M & $\mathrm{Y}$ & Y & Y & $\mathrm{N}$ & $\mathrm{N}$ & & $\mathrm{N}$ & $S$ & $\mathrm{~N}$ & $S$ & $\mathrm{~N}$ & Y & $\mathrm{N}$ & $\mathrm{N}$ \\
\hline Nema and Modak [35] & M & $\mathrm{Y}$ & $\mathrm{N}$ & Y & $\mathrm{N}$ & $\mathrm{N}$ & $\mathrm{N}$ & $\mathrm{N}$ & M & $\mathrm{N}$ & $\mathrm{S}$ & $\mathrm{N}$ & $\mathrm{Y}$ & $\mathrm{N}$ & $\mathrm{Y}$ \\
\hline Nema and Gupta [36] & M & $\mathrm{Y}$ & $\mathrm{N}$ & Y & $\mathrm{N}$ & $\mathrm{N}$ & $\mathrm{N}$ & $\mathrm{N}$ & M & Y & $S$ & $\mathrm{~N}$ & $\mathrm{Y}$ & $\mathrm{N}$ & Y \\
\hline Nema and Gupta [37] & M & $\mathrm{Y}$ & Y & $\mathrm{Y}$ & $\mathrm{N}$ & $\mathrm{N}$ & $\mathrm{N}$ & $\mathrm{N}$ & M & $\mathrm{Y}$ & $S$ & $\mathrm{~N}$ & Y & $\mathrm{N}$ & Y \\
\hline Cappanera et al. [19] & $S$ & $\mathrm{Y}$ & $\mathrm{N}$ & $Y$ & $\mathrm{~N}$ & $\mathrm{~N}$ & $\mathrm{~N}$ & $\mathrm{~N}$ & $S$ & $\mathrm{~N}$ & $S$ & $\mathrm{~N}$ & $\mathrm{Y}$ & $\mathrm{N}$ & $\mathrm{H}$ \\
\hline Alumur and Kara [1] & M & $\mathrm{Y}$ & $\mathrm{N}$ & $\mathrm{Y}$ & $\mathrm{N}$ & $\mathrm{N}$ & $\mathrm{N}$ & $\mathrm{N}$ & M & $\mathrm{Y}$ & $\mathrm{S}$ & $\mathrm{N}$ & Y & $\mathrm{N}$ & Y \\
\hline Erkut et al. [21] & M & $\mathrm{Y}$ & $\mathrm{N}$ & $\mathrm{N}$ & $\mathrm{N}$ & $\mathrm{N}$ & $\mathrm{N}$ & Y & M & $\mathrm{N}$ & $\mathrm{S}$ & $\mathrm{N}$ & Y & $Y$ & Y \\
\hline Boffey et al. [20] & M & $\mathrm{Y}$ & $\mathrm{N}$ & $\mathrm{Y}$ & $\mathrm{N}$ & $\mathrm{N}$ & $\mathrm{N}$ & $\mathrm{N}$ & $\mathrm{S}$ & $\mathrm{N}$ & $\mathrm{S}$ & $\mathrm{N}$ & $\mathrm{N}$ & $\mathrm{N}$ & Y \\
\hline Samanlioglu [6] & M & $\mathrm{Y}$ & $\mathrm{N}$ & $Y$ & $\mathrm{~N}$ & $\mathrm{~N}$ & $\mathrm{~N}$ & $\mathrm{~N}$ & M & Y & $S$ & $\mathrm{~N}$ & Y & Y & Y \\
\hline Jiang et al. [22] & M & $\mathrm{Y}$ & $\mathrm{N}$ & $\mathrm{Y}$ & $\mathrm{N}$ & $\mathrm{N}$ & $\mathrm{N}$ & $\mathrm{N}$ & $\mathrm{M}$ & $\mathrm{N}$ & M & $\mathrm{N}$ & $\mathrm{N}$ & $\mathrm{N}$ & $\mathrm{N}$ \\
\hline Zhao and Verter [24] & M & $\mathrm{Y}$ & $\mathrm{N}$ & $\mathrm{Y}$ & $\mathrm{N}$ & $\mathrm{N}$ & $\mathrm{N}$ & $\mathrm{N}$ & M & $\mathrm{N}$ & $\mathrm{S}$ & Y & Y & $\mathrm{N}$ & Y \\
\hline Zhao et al. [25] & M & $\mathrm{Y}$ & $\mathrm{N}$ & $\mathrm{Y}$ & $\mathrm{N}$ & $\mathrm{N}$ & $\mathrm{N}$ & $\mathrm{N}$ & M & Y & $\mathrm{S}$ & $\mathrm{N}$ & $\mathrm{Y}$ & $\mathrm{Y}$ & Y \\
\hline Yılmaz et al. [26] & M & Y & Y & Y & $\mathrm{N}$ & $\mathrm{N}$ & $\mathrm{N}$ & $\mathrm{N}$ & M & $\mathrm{N}$ & $\mathrm{S}$ & $\mathrm{N}$ & $\mathrm{Y}$ & Y & Y \\
\hline Rabbani et al. [27] & M & $\mathrm{Y}$ & $\mathrm{N}$ & $\mathrm{Y}$ & $\mathrm{N}$ & $\mathrm{N}$ & $\mathrm{N}$ & $\mathrm{N}$ & Y & Y & $\mathrm{S}$ & $\mathrm{N}$ & $\mathrm{Y}$ & $\mathrm{Y}$ & Y \\
\hline Rabbani et al. [28] & M & $\mathrm{Y}$ & $\mathrm{N}$ & $\mathrm{Y}$ & $\mathrm{Y}$ & $\mathrm{Y}$ & $\mathrm{Y}$ & $\mathrm{N}$ & Y & Y & $\mathrm{N}$ & $\mathrm{N}$ & $\mathrm{Y}$ & $\mathrm{Y}$ & Y \\
\hline Karadağ [29] & $S$ & $\mathrm{Y}$ & $\mathrm{N}$ & $\mathrm{N}$ & $\mathrm{N}$ & $\mathrm{N}$ & $\mathrm{N}$ & $\mathrm{Y}$ & $\mathrm{Y}$ & $\mathrm{Y}$ & $\mathrm{N}$ & $\mathrm{N}$ & $\mathrm{Y}$ & $\mathrm{Y}$ & $\mathrm{Y}$ \\
\hline Zhao and Ke [30] & M & $\mathrm{Y}$ & $\mathrm{N}$ & $\mathrm{Y}$ & $\mathrm{N}$ & $\mathrm{N}$ & $\mathrm{Y}$ & $\mathrm{N}$ & $\mathrm{N}$ & $\mathrm{N}$ & $\mathrm{N}$ & $\mathrm{N}$ & $\mathrm{N}$ & $\mathrm{Y}$ & $\mathrm{N}$ \\
\hline Proposed model & $\mathrm{S}$ & $\mathrm{Y}$ & $\mathrm{Y}$ & $\mathrm{Y}$ & $\mathrm{N}$ & $\mathrm{N}$ & $\mathrm{N}$ & $\mathrm{Y}$ & M & $\mathrm{Y}$ & $\mathrm{S}$ & $\mathrm{N}$ & $\mathrm{Y}$ & $\mathrm{Y}$ & $\mathrm{Y}$ \\
\hline
\end{tabular}

OF Objective Function, C Cost, E Equity, R Risk, $T$ Time, ST Stochastic, I Inventory, RV Revenue, W Waste Type, TC Technology Compatibility, TM Transportation Mode, WTF Waste Treatment Facility, WRF Waste Recycling Facility, WDF Waste Disposal Facility, M Multi Objective, S Single Objective, $Y$ Yes, $N$ No into account by Alidi [34] and Erkut et al. [21]. In the proposed hazardous waste management model, both of them are included in the objective function.

A formulation inversely proportional to the population affected by the amount of wastes processed in the facilities and the linear distances to the facility location sites is used to contain the equity in the hazardous waste management model of Marmara region application. The risk/ undesirable effects of the waste is modelled by considering the population within the 1000 m outer boundary of the facilities and the road route that will be affected.

In the literature, the technology compatibility is considered only in the waste treatment facilities. The proposed hazardous waste management model includes technology compatibility for all three facility types.

The hazardous waste management model includes the flow of waste residues from the waste generation centres to the disposal facilities. The proposed hazardous waste management model contributes to many criteria and features including risk, cost, recycling and energy gain, balance and technology compatibility for all facilities in the same model.

\section{An application of the hazardous waste management model in the Marmara Region in Turkey}

In this section, the hazardous waste management model is applied to Marmara region of Turkey by using the actual data obtained. In the model, the hazardous waste generation centres are assumed to be industrial waste generating plants, power plants or residential areas generating domestic wastes. Recyclable wastes which are generated at hazardous waste production centres are sent to recycling facilities. The wastes to be disposed are forwarded to disposal facilities while the other wastes are sent to hazardous waste treatment plants for processing. In the hazardous waste treatment facilities, those that can be recycled from the wastes treated by the compatible waste treatment technology are sent to recycling facilities. Remaining wastes are disposed after they are brought into appropriate disposable form. The energy recovery came by during incineration is considered as a cost-reducing income. Similarly, there is an income from recycled materials in waste recycling facilities. The waste residues are disposed at the 
disposal facilities. The flow of the materials in the system is shown in Fig. 1. The model is a single objective model. The objective function includes the minimization of the fixed costs of waste treatment, disposal, recycling facilities, the transportation costs of wastes between facilities and the maximization of the energy recovery obtained at the recycling, waste treatment facilities.

In the Regular Storage Facilities Site Management and Operation Guide of the Republic of Turkey Ministry of Environment and Urbanization, it is stated that the facilities to be installed should be at least $1000 \mathrm{~m}$ away from the human population areas [38]. Based on this principle, the amount of hazardous waste transported, and the population of settlements located $1000 \mathrm{~m}$ to the right and left of the road route is used for the calculation of the undesirable effect in the model.

The equity is calculated by using the function which is developed from a function provided by Giannikos [4]. In Giannikos [4] 's model the equity is inversely proportional to the distance from the site to the location of the facility and proportional to the amount of waste/recycled material. The equity is expressed as a constraint in the model. Thresholds for undesirable effects are determined according to the amount of waste treated, recycled and disposed in the facilities and to the direct distances to the location sites.

In the model, the transportation network where hazardous wastes are transported is defined by $N=\{V$, $A\}$. The nodes of this network are candidate locations for waste treatment facilities, waste disposal facilities and waste recycling facilities. The followings are the assumptions of the model: (1) Different kinds of waste are produced in waste the production centres. (2) There are existing waste processing, disposal and recycling facilities. If required, new facilities can be located in pre-determined candidate location sites. (3) Different technologies can be selected for waste treatment, recycling and disposal facilities. (4) The unit transportation costs of hazardous wastes, waste residues and recycled materials are known. (5) Unit variable costs of facilities are also known. (6) It is assumed that the same types

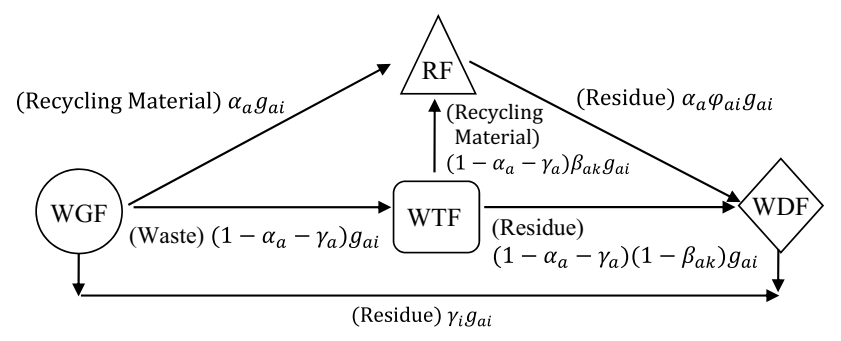

Fig. 1 The flow of the hazardous waste, recycling material and waste residue in the hazardous waste management problem applied to the Marmara Region in Turkey of facilities have the similar capacity, the same fixed and variable costs. (7) Energy recovery is achieved from waste treatment and disposal facilities while some income is obtained from recycling facilities. (8) The unit income from these facilities is on hand and the same values are used for all similar type of facilities in the application problem. (9) All hazardous waste types are transported by using the same type of vehicles with the same cost. (10) The transportation cost depends on the transportation distance and the quantity of the transported material. (11) Recycling materials can be get from hazardous waste generation centres or waste treatment facilities. (12) The ratios of the recycling materials, the hazardous materials to be disposed, which are achieved directly from the hazardous waste generation centres are known and depend on the type of waste. (13) The ratios of recycling materials and waste residues at the treatment facilities are given and depend on the type of the waste. (14) The ratio of the recycled materials at the recycling facilities and the ratio of the residues sent to the disposal facilities are certain.

The indices, parameters and decision variables used in the mathematical model are given below.

\section{Sets:}

$N=(V, A)$ is transportation network; $G$ denotes the waste generation centres where $G \subseteq V ; T$ represents candidate waste treatment facility locations such that $T \subset V ; T A$ is existing candidate waste treatment facility locations where $T A \subset T ; D$ denotes candidate waste disposal facility locations such that $D \subset V ; D A$ stands for existing candidate waste disposal facility locations where $D A \subset D ; R$ represents candidate recycling facility locations where $D \subset V$; $D A$ is existing candidate waste disposal facility locations in such a way that $R \subset V ; R A$ accounts for candidate waste treatment facility locations such that $R A \subset R ; K=\left\{k_{1}, \ldots, k\right\}$ stands for the waste treatment technologies; $B=\left\{b_{1}, \ldots, b\right\}$ is waste disposal technologies; $E=\left\{e_{1}, \ldots, e\right\}$ represents the recycling technologies; $Z=\left\{a_{1}, \ldots, a\right\}$ wherein hazardous waste types and $L$, population centres where $L \subseteq V$.

\section{Parameters:}

$\mathrm{ca}_{i j} \quad$ the cost of transporting one unit of hazardous waste on the line $(i, j) \in A, i \in G, j \in T$,

$c b_{i j} \quad$ the cost of transporting one unit of recycling material on the line $(i, j) \in A, i \in G, j \in R$, the cost of transporting one unit of hazardous material to be disposed on the line $(i, j) \in A, i \in$ $G, j \in D$,

$c d_{i j} \quad$ the cost of transporting one unit of hazardous waste on the line $(i, j) \in A, i \in T, j \in D$, 
$\mathrm{Cr}_{i j} \quad$ the cost of transporting one unit of recycling material on the line $(i, j) \in A, i \in T, j \in R$,

$c s_{i j} \quad$ the cost of transporting one unit of hazardous waste residue on the line $(i, j) \in A, i \in R, i \in D$,

$d s t_{i j} \quad$ the Euclidean distance between $i \in G$ and $j \in V$

$v c t_{k i} \quad$ the variable cost (facility operating cost) for the waste treatment facility with waste treatment technology $k \in K$ located in $i \in T$,

$v c r_{i} \quad$ the variable cost (facility operating cost) for the recycling facility located in $i \in R$,

$v c d_{i} \quad$ the variable cost (facility operating cost) for the recycling facility located in $i \in D$,

$\mathrm{ft}_{k i} \quad$ the fixed cost of opening a waste treatment facility having waste treatment technology $k \in K$ in $i \in T$,

$f d_{b i} \quad$ the fixed cost of opening a waste disposal facility having waste disposal technology $b \in B$ in $i \in D$

$\mathrm{fr}_{e i} \quad$ the fixed cost of opening a waste recycling facility having waste disposal technology $b \in B$ in $i \in R$,

$g_{a i} \quad$ the amount of hazardous waste of type $a \in Z$ generated at the hazardous waste generation centre in $i \in G$,

$\alpha_{a} \quad$ the recycling ratio for type $a \in Z$ hazardous waste generated at the hazardous waste generation centre in $i \in G$,

$\gamma_{a}$ the ratio of waste generated to be disposed for type $a \in Z$ hazardous waste generated at the hazardous waste production centre located in $i \in G$,

$\varphi_{a i} \quad$ the ratio of residues for type $a \in Z$ hazardous waste generated at the hazardous waste recycling facility located in $i \in R$,

$\beta_{a k} \quad$ the recycling rate for type $a \in Z$ hazardous waste treated with waste treatment technology $k \in K$,

$A_{\text {aib }}$ the unit value of the energy recovery obtained from the treatment of hazardous waste type $a \in Z$ with waste treatment technology $b \in Z$ at the waste disposal facility $i \in D$,

$M M_{a i} \quad$ the unit income obtained by the recycling of $a \in Z$ hazardous waste type at node $i \in R$,

$u t_{k i} \quad$ the capacity of the waste treatment facility located at node $i \in T$ which has the waste treatment technology $k \in K$,

$u r_{e i} \quad$ the capacity of the recycling facility with $e \in E$ technology at node $i \in R$,

$u d_{b i} \quad$ the capacity of the $i \in D$ disposal facility with $b \in B$ technology,

$\operatorname{ComT}_{a k}$ hazardous waste treatment technology compatibility parameter: "1" if $a \in Z$ type of hazardous waste is compatible with $k \in K$ waste treatment technology, "0" otherwise,

$\mathrm{com}_{a e}$ hazardous waste recycling technology compatibility parameter: " 1 " if $a \in Z$ type of hazardous waste is compatible with $k \in K$ waste recycling technology, "0" otherwise,

com $D_{a b}$ hazardous waste disposal technology compatibility parameter: "1" if $a \in Z$ type of hazardous waste is compatible with $\mathrm{k} \in \mathrm{K}$ waste disposal technology, "0" otherwise,

lot $_{k i} \quad$ the minimum amount of hazardous waste needed to be treated to open a hazardous waste treatment facility at $i \in T$ having $k \in K$ waste treatment technology,

$\operatorname{lor}_{e i} \quad$ the minimum amount of hazardous recycling material needed to be treated to open a hazardous waste recycling facility at $i \in R$ having $e \in E$ waste treatment technology,

$\operatorname{lod}_{b i}$ the minimum amount of hazardous waste needed to be disposed to open a hazardous waste disposal facility at $i \in D$ having $b \in B$ waste treatment technology,

$\psi t_{\text {aijl }} \quad$ the human population thought to be affected in the $I \in L$ population center due to $a \in Z$ type hazardous waste transported on the road $(i, j)$,

$\psi r_{\text {aijl }}$ the human population thought to be affected in the $I \in L$ population center due to $a \in Z$ type hazardous recycling material transported on the $\operatorname{road}(i, j)$,

$\psi d_{\text {aijl }}$ the human population thought to be affected in the $I \in L$ population center due to $a \in Z$ type hazardous waste residue transported on the $\operatorname{road}(i, j)$,

$\mathrm{POPt}_{i} \quad$ the human population thought to be affected due to locating hazardous waste treatment facilities at the location site $i \in T$,

$\mathrm{POPr}_{i}$ the human population thought to be affected due to locating hazardous waste recycling facilities at the location site $i \in R$,

$\mathrm{POPd}_{i}$ the human population thought to be affected due to locating hazardous waste disposal facilities at the location site $i \in D$,

$\omega t \quad$ equity threshold value for waste treatment facilities,

$\omega r \quad$ equity threshold value for waste recycling facilities,

$\omega d$ equity threshold value for the waste disposal facilities,

$\tau t$ the undesirable effect threshold value for the population centers exposed to the undesirable effect along the route due to the transportation of hazardous waste to the waste treatment facilities, 
$\tau r \quad$ the undesirable effect threshold value for the population centers exposed to the undesirable effect along the route due to the transportation of hazardous recycling material to the waste recycling facilities,

$\tau d$ the undesirable effect threshold value for the population centres exposed to the undesirable effect along the route due to the transportation of hazardous waste residue to the waste disposal facilities,

tt maximum number of waste treatment facilities to be opened,

$v v \quad$ maximum number of waste recycling facilities to be opened,

$n n \quad$ minimum number of waste disposal facilities to be opened.

\section{Decision variables}

$x_{\text {aij }} \quad$ the amount of hazardous waste type $a \in Z$ transported on line $(i, j)$,

$y_{r a}$ the amount of hazardous waste residues carried on line $(i, j) \in A, i \in R, j \in D$ after recycling the hazardous recycling materials coming from waste treatment facilities,

$y r b_{i j}$ the amount of hazardous waste residues carried on the line $(i, j) \in A, i \in R, j \in D$ after recycling the hazardous recycling materials coming from waste generation centers,

$y t_{\text {aij }}$ the amount of hazardous waste residues carried on the line $(i, j) \in A, i \in T, j \in D$ after recycling the hazardous recycling materials coming from waste treatment facilities,

$m g_{\text {aij }}$ the amount of Type $a \in Z$ waste transported on the line $(i, j) \in A, i \in G, j \in R$ to be recycled,

$m t_{\text {aij }}$ the amount of Type $a \in Z$ waste transported on the line $(i, j) \in A, i \in T, j \in R$ to be recycled.

\section{Variables}

$\theta_{a k j} \quad$ the amount of hazardous waste type $a \in Z$ to be treated with technology $k \in K$ at node $i \in T$,

$d t_{a b i}$ the amount of hazardous waste residue of hazardous waste type $a \in Z$ to be treated with technology $b \in B$ at node $i \in D$,

$d r a_{a b i}$ the amount of hazardous waste residues to be disposed by technology $b \in B$ on node $i \in D$, which is formed as a result of the recycling of the $a \in Z$ type waste coming from the waste treatment facilities,

$d r b_{a b i}$ the amount of hazardous waste residues to be disposed by technology $b \in B$ on node $i \in D$, which is formed as a result of the recycling of $a \in Z$ type waste coming from the waste generation centres,

$\delta r_{\text {aei }} \quad$ the amount of type $a \in Z$ waste recycling materials, which are coming from waste generation centres, on node $i \in R$ recycled by using waste recycling technology $e \in E$,

$\delta t_{\text {aei }} \quad$ the amount of type $a \in Z$ waste recycling materials, which are coming from waste treatment facilities, on node $i \in R$ recycled by using waste recycling technology $e \in E$,

$f_{k i} \quad 0-1$ variable which gets value 1 if the waste treatment facility having $k \in K$ waste treatment technology is located on the node $i \in T$, otherwise 0 ,

$n_{b i} \quad 0-1$ variable which gets value 1 if the waste disposal facility having $b \in B$ waste treatment technology is located on the node $i \in D$, otherwise 0 ,

$v_{e i} \quad 0-1$ variable which gets value 1 if the waste recycling facility having $e \in E$ waste treatment technology is located on the node $i \in R$, otherwise 0 ,

\section{Mathematical model}

Minimize Total Cost

$$
\begin{aligned}
& \sum_{i} \sum_{k} f t_{k i} f_{k i}+\sum_{i} \sum_{b} f d_{b i} n_{b i}+\sum_{i} \sum_{e} f r_{e i} v_{e i}+\sum_{(i, j) \in A} \sum_{a} c a_{i j} x_{a i j}+\sum_{(i, j) \in A} \sum_{a} c b_{i j} \\
& +\sum_{(i, j) \in A} \sum_{a} c d_{i j} y t_{a i j}+\sum_{(i, j) \in A} \sum_{a} c r_{i j} m t_{a i j}+\sum_{(i, j) \in A} \sum_{a} c g_{i j} y g_{a i j} \\
& +\sum_{(i, j) \in A} \sum_{a} c s_{i j} y g_{a i j}+\sum_{(i, j) \in A} \sum_{a} c s_{i j} y r b_{a i j}+\sum_{i} \sum_{a} \sum_{k} v c t_{k i} \theta_{a i k} \\
& +\sum_{i} \sum_{a} \sum_{e} v c r_{e i} \delta r_{a e i}+\sum_{i} \sum_{a} \sum_{e} v c r_{e i} \delta t_{a e i}+\sum_{i} \sum_{a} \sum_{b} v c d_{b i} d t_{a b i} \\
& +\sum_{i} \sum_{a} \sum_{b} v c d_{b i} d r_{a b i}-\sum_{i} \sum_{a} \sum_{b} A_{a i b} d t_{a b i}-\sum_{i} \sum_{a} \sum_{b} A_{a i b} d g_{a b i} \\
& \quad-\sum_{i} \sum_{a} \sum_{e} M_{a e i} \delta t_{a e i}-\sum_{i} \sum_{a} \sum_{e} M_{a e i} \delta r_{a e i}
\end{aligned}
$$




\section{Constraints:}

$\left(1-\alpha_{a}-\gamma_{a}\right) g_{a i}-\sum_{k} \theta_{a k i}=\sum_{j:(i, j) \in A} x_{a i j}-\sum_{j:(j, i) \in A} x_{a j i} ; \quad a \in Z, i \in V$

$\gamma_{a} g_{a i}-\sum_{b} d g_{a b i}=\sum_{j:(i, j) \epsilon A} y g_{a i j}-\sum_{j:(j, i) \epsilon A} y g_{a j i} ; \quad a \in Z, i \in V$

$\alpha_{a} g_{a i}-\sum_{e} \delta r_{a e i}=\sum_{j:(i, j) \in A} m g_{a i j}-\sum_{j:(j, i) \in A} m g_{a j i} ; \quad a \in Z, i \in V$

$\left(1-\alpha_{a}-\gamma_{a}\right) g_{a i} \beta_{a k}-\sum_{e} \delta t_{a e i}=\sum_{j:(i, j) \epsilon A} m t_{a i j}$

$-\sum_{j:(j, i) \in A} m t_{a j i} ; \quad a \in Z, i \in V$

$\left(1-\alpha_{a}-\gamma_{a}\right) g_{a i}\left(1-\beta_{a k}\right)-\sum_{b} d t_{a b i}=\sum_{j:(i, j) \in A} y t_{a i j}$

$-\sum_{j:(j, i) \in A} y t_{a j j i} \quad a \in Z, i \in V$

$$
\begin{aligned}
& \left(1-\alpha_{a}-\gamma_{a}\right) \beta_{a k} \varphi_{a}-\sum_{b} d r a_{a b i}=\sum_{j:(i, j) \epsilon A} y r a_{a i j} \\
& \quad-\sum_{j:(j, i) \in A} y r a_{a j i} ; \quad a \in Z, i \in V \\
& \alpha_{a} g_{a i} \varphi_{a}-\sum_{b} d r b_{a b i}=\sum_{j:(i, j) \epsilon A} y r b_{a i j}-\sum_{j:(j, i) \in A} y r a_{a j i} ; \quad a \in Z, i \in V
\end{aligned}
$$

$$
\sum_{a} \sum_{k} \theta_{a k i}=0 ; \quad i \in(V-T)
$$

$\sum_{a} \sum_{b} d t_{a b i}=0 ; \quad i \in(V-D)$

$\sum_{a} \sum_{b} d r a_{a b i}=0 ; \quad i \in(V-D)$

$\sum_{a} \sum_{b} d r b_{a b i}=0 ; \quad i \in(V-D)$

$\sum_{a} \sum_{b} \delta t_{a e i}=0 ; \quad i \in(V-R)$

$\sum_{a} \sum_{b} \delta r_{a e i}=0 ; \quad i \in(V-R)$

$\sum_{i} \sum_{k} f_{k i} \leq t t$

$\sum_{i} \sum_{k} v_{e i} \leq v v$

$\sum_{a} \theta_{a k i} \leq u t_{k i} f_{k i} ; \quad k \in K, i \in T$

$\sum_{a} d g_{a b i}+\sum_{a} d t_{a b i}+\sum_{a} d r a_{a b i}+\sum_{a} d r b_{a b i} \leq u d_{b i} n_{b i} ; \quad b \in B, i \in D$

$\sum_{a} \delta r_{a e i}+\sum_{a} \delta t_{a e i} \leq u r_{e i} v_{e i} ; \quad e \in E, i \in R$

$\theta_{a k i} \leq u t_{k i} \operatorname{ComT}_{a k i} f_{k i} ; \quad a \in Z, k \in K, i \in T$

$\delta t_{a e i}+\delta r_{a e i} \leq u r_{e i} \operatorname{ComR}_{a e i} n_{b i} ; \quad a \in Z, e \in E, i \in R$

$\sum_{i} \sum_{b} n_{b i} \leq n n ;$

$\sum_{a} \theta_{a k i} \geq \operatorname{lot}_{k i} f_{k i} ; \quad k \in K, \quad i \in T$

$\sum_{a} d t_{a b i}+\sum_{a} d r a_{a b i}+\sum_{a} d r b_{a b i} \geq \operatorname{lod}_{b i} n_{b i} ; \quad b \in B, i \in D$

$\sum_{a} \delta r_{a e i}+\sum_{a} \delta_{a e i} \leq l o r_{e i} v_{e i} ; \quad e \in E, i \in R$

$\sum_{(i, j) \in A} \sum_{a} \psi t_{i j} X_{a i j} \leq \tau t ; \quad a \in Z$

$\sum_{(i, j) \in A} \sum_{a} \psi r_{i j} m t_{a i j} \leq \tau r ; \quad a \in Z$

$d g_{a b i}+d t_{a b i}+d r a_{a b i}+d r b_{a b i} \leq u d_{b i} \operatorname{ComD}_{a b i} v_{e i} ; \quad a \in Z, e \in E, i \in R$

$\sum_{(i, j) \in A} \sum_{a} \psi r_{i j} m g_{a i j} \leq \tau r ; \quad a \in Z$

$f_{k i}=1 ; \quad k \in K, \quad i \in T$

$n_{b i}=1 ; \quad b \in B, \quad i \in D$

$\sum_{(i, j) \in A} \sum_{a} \psi d_{i j} y t_{a i j} \leq \tau d ; \quad a \in Z$

$v_{e i}=1 ; \quad e \in E, \quad i \in R$ 


$$
\sum_{(i, j) \in A} \sum_{a} \psi d_{i j} y r_{a i j} \leq \tau d ; \quad a \in Z
$$

$$
\sum_{i} \sum_{a} \sum_{k} \frac{P O P t_{i} \theta_{a k i}}{d s t_{i j}} \leq \omega t ; \quad j \in V
$$

$$
\sum_{i} \sum_{a} \sum_{e} \frac{P O P r_{i}\left(\delta r_{a e i}+\delta t_{a e i}\right)}{d s t_{i j}} \leq \omega r ; \quad j \in V
$$

$$
\sum_{i} \sum_{a} \sum_{b} \frac{P O P d_{i}\left(d t_{a b i}+d r a_{a b i}+d r b_{a b i}\right)}{d s t_{i j}} \leq \omega d ; \quad j \in V
$$

$$
f_{k i} \in\{0,1\}, k \in K, i \in T
$$

$f d_{b i} \in\{0,1\}, b \in B, i \in D$

$f r_{e i} \in\{0,1\}, e \in E, i \in R$

$\theta_{a k i} \geq 0, a \in Z, k \in K, i \in T$

$x_{a i j}, y t_{a i j}, y r a_{a i j}, y r b_{a i j}, m t_{a i j}, m g_{a i j} \geq 0, \quad a \in Z,(i, j) \in A$

$d t_{a b i} \geq 0 ; \quad a \in Z, b \in B, i \in D$

$d r a_{a b i} \geq 0 ; \quad a \in Z, b \in B, i \in D$

$d r b_{a b i} \geq 0 ; \quad a \in Z, b \in B, i \in D$

$\delta r_{a e i}, \delta t_{a e i} \geq 0 ; \quad a \in Z, e \in E, i \in R$

In the model, the objective function (2.1) minimizes the fixed and variable costs of treatment, recycling and disposal facilities and the transportation costs of transporting the wastes, recycling materials and waste residues between these facilities; maximizes the energy recovery achieved in the waste disposal facilities and the income achieved in the recycling facilities. Equations (2.2)-(2.8) are flow-balance constraints. Equations (2.9)-(2.11) denote the facility capacity constraints. Equations (2.12)-(2.14) represents the compatibility constraints for the compatibility of wastes, recycling materials and waste residues with the facility technologies. Equations (2.15)-(2.17) stands for the constraints that stand for existing facilities. Equations (2.18)-(2.23) are the constraints that do not allow for the treatment of the wastes outside of the related facilities. Equations (2.24)-(2.26) stand for the constraints for the maximum number of facilities that are allowed to be opened. Equations (2.27)-(2.29) give the constraints stating that the facilities cannot be located without a certain amount of wastes, recycled materials and waste residues are treated. Equations (2.30)-(2.34) denote the transportation risk (undesirable effect) constraints. Equations (2.35)-(2.37) are equity constraints. Equations (2.38)-(2.40) stand for the constraints that are stating the $0-1$ variables. Finally, Eq. (2.41)-(2.46) are the non-negativity constraints.

\subsection{Data}

There are 394 hazardous wastes defined by waste codes in the Waste Management Regulation of The Republic of Turkey Ministry of Environment and Urbanization (RTMEU) [2]. The top ten hazardous waste codes and waste amounts declared to be the most in 2014 are given in the Bulletin of Hazardous Waste Statistics of the 2014 Yearbook of RTMEU [39]. These are the wastes with the code numbers: $100207,150110,170503,180103,110105$, $120120,190813,150202,040219$ and 050103. The first 10 of the highest amount of wastes, which is declared on the waste code basis, constitutes $66 \%$ of the total wastes declared in 2014 [39]. For this reason, in the application for the Marmara region, the top ten types of waste produced in the Marmara region are considered. The data is provided by the RTMEU [40].

Disposal and recycling of hazardous wastes are included in the Waste Management Regulation of the RTMEU [2]. Accordingly, there are 15 disposal and 13 recycling methods. When the hazardous waste types of the Marmara Region and the processes used for these wastes examined, we see that all of the hazardous wastes are processed by at least one of the following technologies:

1. Hazardous waste treatment facilities: R12 and R9;

2. Hazardous waste recycling facilities: R1, R4 and R5;

3. Hazardous waste disposal facilities: D5 and D10.

Thus, only seven of the methods above-mentioned are considered in practice.

Marmara region has 157 population centres including 11 cities and 146 towns. In the application, a total of 44 population centres are considered. Total capacities are taken into account for each facility location. In Marmara region, the existing facilities and the candidate facility locations are indicated in Table 2 on a technology basis.

In the preliminary feasibility report prepared by Gaziantep Chamber of Industry in 2012, the number of facilities in Turkey and their waste treatment capacities considering their technologies are indicated [41]. The total amount of waste declared as "waste" in the Hazardous Waste Declaration System has increased by 0.5 times between 2011 and 
Table 2 The existing and the candidate facilities

\begin{tabular}{|c|c|c|c|c|c|c|c|}
\hline \multirow[t]{2}{*}{ No } & \multirow[t]{2}{*}{ Locations } & \multicolumn{2}{|c|}{ Waste treatment facility } & \multicolumn{2}{|c|}{ Waste recycling facility } & \multicolumn{2}{|c|}{ Waste disposal facility } \\
\hline & & Existing & Candidate & Existing & Candidate & Existing & Candidate \\
\hline 1 & Balikesir & R12, D9 & & $\mathrm{R} 4, \mathrm{R} 1$ & & D10 & \\
\hline 2 & Bandirma & & & & & & \\
\hline 3 & Bilecik & $\mathrm{R} 12$ & & $\mathrm{R} 4, \mathrm{R} 1$ & & & \\
\hline 4 & Bursa & $\mathrm{R} 12$ & & $\mathrm{R} 4, \mathrm{R} 1$ & & & \\
\hline 5 & Nilufer & $\mathrm{R} 12$ & & R4, R1 & & & $X$ \\
\hline 6 & Osmangazi & $\mathrm{R} 12$ & & $\mathrm{R} 4, \mathrm{R} 1$ & & & $x$ \\
\hline 7 & Inegol & $\mathrm{R} 12$ & & R4, R1 & & & $\mathrm{X}$ \\
\hline 8 & Gemlik & $\mathrm{R} 12$ & & R1 & & & \\
\hline 9 & Orhangazi & & & & & & $x$ \\
\hline 10 & Kestel & & & & $x$ & D5, D10 & \\
\hline 11 & Canakkale & D9 & & & & & \\
\hline 12 & Ezine & & & & & D10 & \\
\hline 13 & Biga & $\mathrm{R} 12$ & & & $\mathrm{X}$ & & \\
\hline 14 & Edirne & & $x$ & & $\mathrm{x}$ & & $x$ \\
\hline 15 & Lalapasa & & & & $x$ & D5 & \\
\hline 16 & Basaksehir & & $x$ & & $x$ & & \\
\hline 17 & Esenyurt & $\mathrm{R} 12$ & & R1 & & & \\
\hline 18 & Tuzla & $\mathrm{R} 12$ & & $\mathrm{R} 4, \mathrm{R} 1$ & & & $\mathrm{X}$ \\
\hline 19 & Bagcilar & & $X$ & R4 & & & $X$ \\
\hline 20 & Kucukcekmece & & $x$ & & $x$ & & $x$ \\
\hline 21 & Pendik & & $x$ & $\mathrm{R} 4, \mathrm{R} 1$ & & & $x$ \\
\hline 22 & Silivri & & $X$ & R4 & & & $X$ \\
\hline 23 & Arnavutkoy & & $\mathrm{X}$ & R4 & & & $\mathrm{X}$ \\
\hline 24 & Kirklareli & & $X$ & R4 & & & $\mathrm{X}$ \\
\hline 25 & Pınarhisar & & $x$ & & $x$ & & $x$ \\
\hline 26 & Vize & & $x$ & & $x$ & D10 & \\
\hline 27 & Luleburgaz & D9 & & & $X$ & & $x$ \\
\hline 28 & Kocaeli & $\mathrm{R} 12$ & & R4, R1 & & & $\mathrm{X}$ \\
\hline 29 & İzmit & D9 & & & $X$ & D5, D10 & \\
\hline 30 & Başiskele & & $x$ & $\mathrm{R} 4, \mathrm{R} 1$ & & & $x$ \\
\hline 31 & Derince & & $x$ & & $x$ & & $x$ \\
\hline 32 & Darica & & $x$ & & $x$ & D5, D10 & \\
\hline 33 & Korfez & & $\mathrm{X}$ & & $\mathrm{X}$ & D5, D10 & \\
\hline 34 & Çayirova & $\mathrm{R} 12$ & & R1 & & & $X$ \\
\hline 35 & Dilovasi & & $x$ & R1 & & & $x$ \\
\hline 36 & Gebze & & $\mathrm{X}$ & & $X$ & & $\mathrm{X}$ \\
\hline 37 & Sakarya & $\mathrm{R} 12, \mathrm{D} 9$ & & $\mathrm{R} 4, \mathrm{R} 1$ & & & $x$ \\
\hline 38 & Erenler & $\mathrm{R} 12$ & & & $X$ & & $\mathrm{X}$ \\
\hline 39 & Tekirdağ & D9 & & & $X$ & & $\mathrm{X}$ \\
\hline 40 & Çerkezköy & $\mathrm{R} 12$ & & R4 & & & $\mathrm{X}$ \\
\hline 41 & Ergene & $\mathrm{R} 12$ & & R4 & & & $x$ \\
\hline 42 & Çorlu & $\mathrm{R} 12$ & & $\mathrm{R} 5, \mathrm{R} 4, \mathrm{R} 1$ & & D5, D10 & \\
\hline 43 & Kapakli & & $\mathrm{X}$ & R4 & & & $x$ \\
\hline 44 & Yalova & $\mathrm{R} 12$ & & R1 & & & $\mathrm{X}$ \\
\hline Existing facilities & & 18 R12, 6 D9 & & 1 R5, 19 R4, 17 R1 & & 6 D5, 8 D10 & \\
\hline Total & & 24 & 17 & 37 & 16 & 14 & 27 \\
\hline
\end{tabular}


2014 in the hazardous waste statistics of 2014 which is prepared by the Ministry of Environment and Urbanization [39]. In this study, it is assumed that the average capacities of facilities are increased by 0.5 times. In this case it is assumed to be $34,399,564 \mathrm{~kg}$ for R1, 10,009,587 kg for R4, $733,125 \mathrm{~kg}$ for R5, 5,231,785 kg for R12 and D9. For D10, the capacity of IZAYDAS is taken as $35,000,000 \mathrm{~kg}$ and for D5 the hazardous waste storage capacity of IZAYDAS is taken as $25,000,000 \mathrm{~kg}[41,42]$.

In the energy income calculations, the averages of the data obtained from AKCANSA cement factories and IZAYDAS are used [42-44]. Accordingly, $0.544 \mathrm{kWh}$ electrical energy is produced from $1 \mathrm{~kg}$ hazardous waste in AKCANSA, $0.530 \mathrm{kWh}$ electrical energy is produced from $1 \mathrm{~kg}$ waste in IZAYDAS. In the calculations, a value of $0.537 \mathrm{kWh} / \mathrm{kg}$, which is the average of the two values, is used. $1 \mathrm{kWh}$ electrical energy is 1.08 US Dollars, the gain from $1 \mathrm{~kg}$ hazardous waste is 0.580 US Dollars $[45,46]$. The income from $1 \mathrm{~kg}$ waste oil is taken as 0.3 USD in the calculations of the recycling gain obtained by using $\mathrm{R} 1$ technology $[47,48]$.

Annual depreciation values are taken as facility installation costs in the calculations within the problem. Accordingly, the facility installation cost is 919,719 US Dollars for the waste treatment facilities having $R 12$ and D9 recycling technologies [46, 49-51], the facility installation cost is 105,000 US Dollars for the waste recycling facilities having R1, R4 and R5 recycling technologies $[48,49]$, the facility installation cost is $2,619,780$ US Dollars for the waste disposal facilities having D5 disposal technology and the facility installation cost is $3,716,000$ US Dollars for the waste disposal facilities having D10 disposal technology [46, 49-51].

For the variable costs, the unit incineration, waste storage and recycling costs are 0.3344 US Dollars/ kg, 0.07803 US Dollars/kg, 0.9385 US Dollars/kg and 0.1672 US Dollars/kg respectively $[46,49,50]$.

The recycling/residue rates and the information about the hazardous waste type/technology compatibility, which
Table 3 The hazardous waste recycling and hazardous waste residue rates
Table 4 The compatibility of hazardous waste treatment facilities with the waste types

\begin{tabular}{llllll}
\hline No & Waste no. & \multicolumn{2}{l}{ Waste generation centers } & $\begin{array}{l}\text { Waste treatment facil- } \\
\text { ity recycling ratio }\end{array}$ & $\begin{array}{l}\text { Waste recycling facil- } \\
\text { ity waste residue ratio }\end{array}$ \\
\cline { 3 - 5 } & Recycling ratio & $\begin{array}{l}\text { Waste resi- } \\
\text { due ratio }\end{array}$ & \\
\hline 1 & 100207 & 1 & 0 & 0 & 0 \\
2 & 150110 & 0.044 & 0.022 & 0.7314 & 0.05 \\
3 & 170503 & 0 & 0.776 & 0 & 0 \\
4 & 180103 & 0.0037 & 0.044 & 0.7314 & 0.05 \\
5 & 110105 & 1 & 0 & 0 & 0 \\
6 & 120120 & 0.58 & 0.0002 & 0.7314 & 0.05 \\
7 & 190813 & 0.139 & 0.034 & 0.7314 & 0.05 \\
8 & 150202 & 0.286 & 0.045 & 0.7314 & 0.05 \\
9 & 040219 & 0.00057 & 0.0086 & 0.7314 & 0.05 \\
10 & 050103 & 0.40 & 0.020 & 0.7314 & 0.05 \\
\hline
\end{tabular}

\begin{tabular}{|c|c|c|c|c|c|c|c|}
\hline \multirow[t]{2}{*}{ Waste no. } & \multicolumn{2}{|c|}{$\begin{array}{l}\text { Waste treatment technol- } \\
\text { ogy compatibility }\end{array}$} & \multicolumn{3}{|c|}{$\begin{array}{l}\text { Waste recycling technology compat- } \\
\text { ibility }\end{array}$} & \multicolumn{2}{|c|}{$\begin{array}{l}\text { Waste disposal } \\
\text { technology } \\
\text { compatibility }\end{array}$} \\
\hline & $\mathrm{R} 12$ & D9 & $\mathrm{R} 1$ & $\mathrm{R} 4$ & R5 & D5 & D10 \\
\hline 100207 & - & - & - & - & - & - & - \\
\hline 150110 & + & - & + & + & - & + & + \\
\hline 170503 & + & - & - & - & - & + & + \\
\hline 180103 & + & + & - & - & + & - & + \\
\hline 110105 & - & - & - & - & + & - & - \\
\hline 120120 & + & - & - & + & - & + & + \\
\hline 190813 & + & - & + & + & - & + & + \\
\hline 150202 & + & - & + & + & - & + & + \\
\hline 040219 & + & - & + & - & - & + & - \\
\hline 050103 & + & - & + & - & - & - & + \\
\hline
\end{tabular}


is derived from the data on 10 types of hazardous waste, obtained from RTMEU are in Tables 3 and 4, respectively [40]. Due to the lack of data about residue rates, which is sent from the waste treatment facilities to the waste disposal facilities; as in the Alumur and Kara [1] and Samanlioglu [6] the rate 0.05 .

Equations (2.50)-(2.52) are the formulas for the threshold values that are used in the hazardous waste transportation undesirable effect constraints. The $n t$ is ratio of undesirable effect for hazardous waste transported to hazardous waste treatment facilities. The $n r$ is the ratio of undesirable effect for hazardous waste transported to hazardous waste recycling facilities and the $n d$ is the ratio of undesirable effect for hazardous waste transported to hazardous waste disposal facilities. The values of these ratios are assumed to be $n t=0.01, n r=0.1$ and $n d=0.01$ for the application.

$$
\begin{aligned}
& \tau t=n t \sum_{(i, j) \in A} \psi t_{i j}\left(1-\alpha_{a}-\gamma_{a}\right) g(a, i), \quad a \in Z \\
& \tau r=n r \sum_{(i, j) \in A} \psi r_{i j}\left(\alpha_{a} g_{a i}+\left(1-\alpha_{a}-\gamma_{a}\right) g_{a i} \beta_{a k}\right), \quad a \in Z, k \in K
\end{aligned}
$$

The actual road distances and the bird's flight distances between the residential areas are obtained by using the ArcGIS software.

\subsection{Results}

The application of the hazardous waste management model with the Marmara region data was primarily carried out with the available data. Then, the maximum number of hazardous waste treatment facilities and the minimum amount of hazardous waste required for the location of the facility are applied by assuming certain values.

The application problem of the hazardous waste management model with Marmara region data was solved via the best solution value of $295,220,771.52$ USD in $10 \mathrm{~s}$ by using Intel Core i5-4200U 1.6 GHZ microprocessor and GAMS 148 CPLEX 10.2.0 software. Table 5 summarizes the results of the application in the Marmara region, including new facilities opened and their technologies. Accordingly, in addition to the existing 18 facilities having R12 and 6 facilities having D9 waste treatment technology, 3 facilities having R12 hazardous waste treatment technol-

$\tau d=n d \sum_{(i, j) \in A} \psi d_{i j}\left(\left(1-\alpha_{a}-\gamma_{a}\right) g_{a i}-\left(1-\beta_{a k}\right)+\alpha_{a} g_{a i} \varphi_{a}+\gamma_{a} g_{a i}\right), \quad a \in Z, k \in K$

Equations (2.50)-(2.52) are the formulas for the equity threshold values. The $p t_{i}$ is the ratio of the undesirable effects for the hazardous waste treatment facilities to the population centres. The $p r_{i}$ is the ratio of the undesirable effects for hazardous waste recycling facilities to the population centers and the $p d_{i}$, the ratio of the undesirable effects of hazardous waste disposal facilities to the population centres.

The values of these ratios are assumed to be $p t_{i}=1000$, $p r_{i}=1000$ and $p d_{i}=1,000,000$ for the application.

$\mathrm{POPt}_{i}, \mathrm{POPr}_{i}, \mathrm{POPd}_{i}$ are the population exposed to the undesirable effect in the area $1000 \mathrm{~m}$ outside the border of facilities.

$$
\begin{aligned}
& \omega t=p t_{i} \sum_{a} \sum_{i} \operatorname{POPt}_{i}\left(1-\alpha_{a}-\gamma_{a}\right) g_{a i} \\
& \omega r=p r_{i} \sum_{a} \sum_{k} \sum_{i} \operatorname{POPr}_{i}\left(\alpha_{a} g_{a i}+\left(1-\alpha_{a}-\gamma_{a}\right) \beta_{a k} g_{a i}\right.
\end{aligned}
$$

$\omega d=p d_{i} \sum_{a} \sum_{k} \sum_{i} P O P d_{i}\left(\left(1-\alpha_{a}-\gamma_{a}\right) \beta_{a k} g_{a i}+\alpha_{a} \varphi_{a} g_{a i}+\gamma_{a} g_{a i}\right)$, ogy are opened. With the existing 1 facility having R5, 19 facilities having $R 4$ and 18 facilities having $R 1$ waste recycling technology, 22 facilities having R5, 3 facilities having R1 and 7 facilities having R4 waste recycling technologies are located. Finally, in addition to the existing 6 facilities having D5 and 8 facilities having D10 waste treatment technology, 2 facilities having D5 and 1 facilities having D10 hazardous waste disposal technologies are opened.

Despite the maximum number of facilities may be a decision of governments or local authorities, the minimum amount of hazardous waste required for the opening of facilities is related to both administrative and cost-effective factors.

Table 6 summarizes the results that are achieved in case of an increase in the threshold value of the equity/transportation undesirable effects. Accordingly, the increase in the threshold values of the equity/transportation undesirable effects by $10 \%$ and $20 \%$, has a decreasing effect on the cost due to an increase in the number of facilities and a change in the location of them.

Table 7 summarizes how the model works with the maximum facility and minimum waste quantity constraints. For this purpose, the maximum number of facilities that can be opened is taken as 45,35 and 30 for hazardous waste treatment facilities; 85,75 and 65 for hazardous waste 
Table 5 New facilities to be opened after solution

\begin{tabular}{|c|c|c|c|}
\hline Location & $\begin{array}{l}\text { Waste treatment } \\
\text { facility }\end{array}$ & Waste recycling facility & Waste disposal facility \\
\hline Balıkesir & & R5 & \\
\hline Bursa & & R5 & \\
\hline Nilüfer & & & D5 \\
\hline Ezine & & R4 & \\
\hline Biga & & R4 & \\
\hline Edirne & & $\mathrm{R} 1$ & \\
\hline Başakşehir & & R5 & \\
\hline Esenyurt & & R5 & \\
\hline Tuzla & & R5 & \\
\hline Bağcılar & & R5 & \\
\hline Küçükçekmece & & R5 & \\
\hline Pendik & & R5 & \\
\hline Arnavutköy & & R5 & \\
\hline Kırklareli & & $\mathrm{R} 5, \mathrm{R} 1$ & \\
\hline Kocaeli & & R5 & \\
\hline İzmit & & R5 & \\
\hline Başiskele & & R5 & \\
\hline Derince & & R5 & \\
\hline Darıca & & $\mathrm{R} 5, \mathrm{R} 4$ & \\
\hline Körfez & $\mathrm{R} 12$ & $\mathrm{R} 5, \mathrm{R} 4$ & \\
\hline Çayırova & & $\mathrm{R} 5, \mathrm{R} 4$ & \\
\hline Dilovası & $\mathrm{R} 12$ & $\mathrm{R} 5, \mathrm{R} 4$ & $\mathrm{D} 5, \mathrm{D} 10$ \\
\hline Gebze & $\mathrm{R} 12$ & $\mathrm{R} 5, \mathrm{R} 4$ & \\
\hline Sakarya & & R5 & \\
\hline Erenler & & R5 & \\
\hline Tekirdağ & & $\mathrm{R} 4, \mathrm{R} 1$ & \\
\hline Yalova & & R5 & \\
\hline $\begin{array}{l}\text { New facilities to be } \\
\text { opened }\end{array}$ & $3 \mathrm{R} 12$ & $22 \mathrm{R} 5,3 \mathrm{R} 1,8 \mathrm{R} 4$ & $2 \mathrm{D} 5,1 \mathrm{D} 10$ \\
\hline Total & 3 & 33 & 3 \\
\hline
\end{tabular}

recovery plants and 30, 20 and 18 for hazardous waste disposal facilities. The minimum amount of hazardous waste that must be delivered to the facilities in order to open the facilities is $10,000 \mathrm{~kg}$ and $11,000 \mathrm{~kg}$ for all plant types.

The results accordingly are: In the solutions get by adding the maximum number of facilities and minimum waste amount constraints to the problem, the number of facilities increases with the determined bounds and the cost decreases. As the minimum amount of hazardous waste required opening a facility increases, the number of facilities decreases and the cost increases.

\section{Conclusions}

The importance of hazardous waste management is increasing due to continuous industrial and technological development, population crowding pose a serious threat to human health and habitat. The hazardous waste facility location and routing models started with Zografos and Samara [16] and increasingly developed from day to day. Models developed in these studies include cost, revenue, risk, balance and time measures; hazardous waste treatment facilities, hazardous waste recycling facilities and 
Table 6 Results of scenarios for equity and transportation undesirable effect constraints

\begin{tabular}{|c|c|c|c|c|c|c|c|c|}
\hline SN & LBE (\%) & LTU (\%) & $\mathrm{NCF}$ & NNF & NTF & OFV (\$) & Difference (\$) & Difference \% \\
\hline 1 & +0 & +0 & $\begin{array}{l}\text { GKT: } 37 \\
\text { BET: } 14 \\
\text { AIT: } 24 \\
\text { Total: } 75\end{array}$ & $\begin{array}{l}\text { GKT: } 33 \\
\text { BET: } 3 \\
\text { AIT: } 3 \\
\text { Total: } 39\end{array}$ & $\begin{array}{l}\text { GKT: } 70 \\
\text { BET: } 17 \\
\text { AIT: } 27 \\
\text { Total: } 114\end{array}$ & $295,220,771.52$ & 0 & 0 \\
\hline 2 & +10 & +10 & $\begin{array}{l}\text { GKT: } 37 \\
\text { BET: } 14 \\
\text { AIT: } 24 \\
\text { Total: } 75\end{array}$ & $\begin{array}{l}\text { GKT: } 33 \\
\text { BET: } 3 \\
\text { AIT: } 4 \\
\text { Total: } 40\end{array}$ & $\begin{array}{l}\text { GKT: } 70 \\
\text { BET: } 17 \\
\text { AIT: } 28 \\
\text { Total: } 115\end{array}$ & $294,520,154.90$ & $700,616.62$ & 0.24 \\
\hline 3 & +10 & +0 & $\begin{array}{l}\text { GKT: } 37 \\
\text { BET: } 14 \\
\text { AIT24 } \\
\text { Total: } 75\end{array}$ & $\begin{array}{l}\text { GKT: } 33 \\
\text { BET: } 3 \\
\text { AIT: } 4 \\
\text { Total: } 40\end{array}$ & $\begin{array}{l}\text { GKT: } 70 \\
\text { BET: } 17 \\
\text { AIT: } 28 \\
\text { Total: } 115\end{array}$ & $295,077,989.71$ & $142,781.81$ & 0.05 \\
\hline 4 & +0 & +10 & $\begin{array}{l}\text { GKT: } 37 \\
\text { BET: } 14 \\
\text { AIT: } 24 \\
\text { Total: } 75\end{array}$ & $\begin{array}{l}\text { GKT: } 33 \\
\text { BET: } 3 \\
\text { AIT: } 4 \\
\text { Total: } 40\end{array}$ & $\begin{array}{l}\text { GKT: } 70 \\
\text { BET: } 17 \\
\text { AIT: } 28 \\
\text { Total: } 115\end{array}$ & $294,667,366.46$ & $553,405.06$ & 0.19 \\
\hline 5 & +20 & +20 & $\begin{array}{l}\text { GKT: } 37 \\
\text { BET: } 14 \\
\text { AIT: } 24 \\
\text { Total: } 75\end{array}$ & $\begin{array}{l}\text { GKT: } 31 \\
\text { BET: } 3 \\
\text { AIT: } 4 \\
\text { Total: } 38\end{array}$ & $\begin{array}{l}\text { GKT: } 68 \\
\text { BET: } 17 \\
\text { AIT: } 28 \\
\text { Total: } 113\end{array}$ & $294,150,452.36$ & $1,070,319.20$ & 0.36 \\
\hline 6 & +20 & +10 & $\begin{array}{l}\text { GKT: } 37 \\
\text { BET: } 14 \\
\text { AIT: } 24 \\
\text { Total: } 75\end{array}$ & $\begin{array}{l}\text { GKT: } 33 \\
\text { BET: } 3 \\
\text { AIT: } 4 \\
\text { Total: } 40\end{array}$ & $\begin{array}{l}\text { GKT: } 70 \\
\text { BET: } 17 \\
\text { AIT: } 28 \\
\text { Total: } 115\end{array}$ & $294,458,335.20$ & $762,436.32$ & 0.26 \\
\hline 7 & +10 & +20 & $\begin{array}{l}\text { GKT: } 37 \\
\text { BET: } 14 \\
\text { AIT: } 24 \\
\text { Total: } 75\end{array}$ & $\begin{array}{l}\text { GKT: } 32 \\
\text { BET: } 3 \\
\text { AIT: } 4 \\
\text { Total: } 39\end{array}$ & $\begin{array}{l}\text { GKT: } 69 \\
\text { BET: } 17 \\
\text { AIT: } 28 \\
\text { Total: } 114\end{array}$ & $294,150,452.36$ & $1,070,319.20$ & 0.36 \\
\hline 8 & +30 & +30 & $\begin{array}{l}\text { GKT: } 37 \\
\text { BET: } 14 \\
\text { AIT: } 24 \\
\text { Total: } 75\end{array}$ & $\begin{array}{l}\text { GKT: } 33 \\
\text { BET: } 3 \\
\text { AIT: } 4 \\
\text { Total: } 40\end{array}$ & $\begin{array}{l}\text { GKT: } 70 \\
\text { BET: } 17 \\
\text { AIT: } 28 \\
\text { Total: } 115\end{array}$ & $293,951,350.28$ & $1,269,421.20$ & 0.43 \\
\hline
\end{tabular}

$S N$ scenario number, LBE lower bound variation for equity, LTU lower bound variation for transportation undesirable effect, NCF number of current facilities, NNF number of new facilities, NTF number of total facilities, OFV objective function value GKT Recycling Facility, BET disposal facility, AIT waste treatment facility disposal facilities; the compatibility of facilities' technologies with hazardous wastes; compatibility of the wastes with each other so that the wastes can be treated at the same facilities; transportation modes; single or multi-product models and so on.

The developed hazardous waste management model with its Marmara region application is a single objective, multi-product model, including cost, revenue, facility/ transportation undesirable effects, equity criteria with the location of hazardous waste treatment facilities, recycling and disposal facilities and the transportation of hazardous wastes between them taking into account the facilityhazardous waste compatibility.
The hazardous waste management model and its application to Marmara region of Turkey with real data is a model that can help to the strategic level decision makers. By using the developed model, it is possible to decide which types of facilities are needed considering the type and amount of hazardous waste generated, at the decision maker level. It is possible to determine where to locate these facilities while minimizing the risk and social response according to the predetermined threshold values. Also, the model determines the types of hazardous waste that can be transported between the facilities. For example, in the direction of the data we have obtained, there is one facility which is licensed by RTMEU in the Marmara region and treated with one $\mathrm{R} 5$ recycling technology. 
Table 7 Results of scenarios with upper bound for number of facilities, lower bound for waste quantity, equity and transportation undesirable effect constraints

\begin{tabular}{|c|c|c|c|c|c|c|c|c|c|c|c|}
\hline \multirow[t]{2}{*}{$\mathrm{SN}$} & \multicolumn{3}{|c|}{ MNF } & \multirow[t]{2}{*}{ LQW } & \multirow[t]{2}{*}{ LTU (\%) } & \multirow[t]{2}{*}{ LBE (\%) } & \multicolumn{3}{|l|}{ Facilities } & \multirow[t]{2}{*}{ OFV difference (\$) } & \multirow[t]{2}{*}{$\mathrm{D} \%$} \\
\hline & AIT & GKT & BET & & & & $\mathrm{NCF}$ & NNF & NTF & & \\
\hline \multirow[t]{4}{*}{9} & 45 & 85 & 30 & 10,000 & +0 & +0 & GKT: 37 & GKT: 33 & GKT: 70 & $-18,728.83$ & -0.06 \\
\hline & & & & & & & BET: 14 & BET: 3 & BET: 17 & & \\
\hline & & & & & & & AIT: 24 & AIT: 4 & AIT: 28 & & \\
\hline & & & & & & & Top.: 75 & Top: 40 & Top: 115 & & \\
\hline \multirow[t]{4}{*}{10} & 45 & 85 & 30 & 10,000 & +10 & +10 & GKT: 37 & GKT: 33 & GKT70 & $681,892.81$ & 0.23 \\
\hline & & & & & & & BET: 14 & BET: 3 & BET: 17 & & \\
\hline & & & & & & & AIT: 24 & AIT: 4 & AIT: 28 & & \\
\hline & & & & & & & Top.: 75 & Top.: 40 & Top.: 115 & & \\
\hline \multirow[t]{4}{*}{11} & 45 & 85 & 30 & 10,000 & +10 & +0 & GKT: 37 & GKT: 34 & GKT: 71 & $82,124.52$ & 0.03 \\
\hline & & & & & & & BET: 14 & BET: 3 & BET: 17 & & \\
\hline & & & & & & & AIT: 24 & AIT: 4 & AIT: 28 & & \\
\hline & & & & & & & TOP: 75 & TOP: 41 & TOP: 115 & & \\
\hline \multirow[t]{4}{*}{12} & 45 & 85 & 30 & 10,000 & +0 & +10 & GKT: 37 & GKT: 33 & GKT: 70 & $534,681.27$ & 0.18 \\
\hline & & & & & & & BET: 14 & BET: 3 & BET: 17 & & \\
\hline & & & & & & & AIT: 24 & AIT: 4 & AIT: 28 & & \\
\hline & & & & & & & Top.: 75 & Top.: 40 & Top.: 115 & & \\
\hline \multirow[t]{4}{*}{13} & 45 & 85 & 30 & 10,000 & +20 & +20 & GKT: 37 & GKT: 32 & GKT: 69 & $794,932.79$ & 0.27 \\
\hline & & & & & & & BET: 14 & BET: 3 & BET: 17 & & \\
\hline & & & & & & & AIT: 24 & AIT: 4 & AIT: 28 & & \\
\hline & & & & & & & Top.: 75 & Top.: 39 & Top.: 114 & & \\
\hline \multirow[t]{4}{*}{14} & 45 & 85 & 30 & 10,000 & +10 & +20 & GKT: 37 & GKT: 33 & GKT: 70 & $749,126.45$ & 0.25 \\
\hline & & & & & & & BET: 14 & BET: 3 & BET: 17 & & \\
\hline & & & & & & & AIT: 24 & AIT: 4 & AIT: 28 & & \\
\hline & & & & & & & Top.: 75 & Top.: 40 & Top.: 115 & & \\
\hline \multirow[t]{4}{*}{15} & 45 & 85 & 30 & 10,000 & +20 & +10 & GKT: 37 & GKT: 33 & GKT: 70 & $1,051,599.8$ & 0.36 \\
\hline & & & & & & & BET: 14 & BET: 3 & BET: 17 & & \\
\hline & & & & & & & AIT: 24 & AIT: 4 & AIT: 28 & & \\
\hline & & & & & & & Top.: 75 & Top.: 40 & Top.: 115 & & \\
\hline \multirow[t]{4}{*}{16} & 35 & 75 & 20 & 10,000 & +0 & +0 & GKT: 37 & GKT: 33 & GKT: 70 & $-18,728.83$ & -0.06 \\
\hline & & & & & & & GKT: 14 & GKT: 5 & GKT: 17 & & \\
\hline & & & & & & & AIT: 24 & AIT: 4 & AIT: 28 & & \\
\hline & & & & & & & Total: 75 & Total: 42 & Total: 115 & & \\
\hline \multirow[t]{4}{*}{17} & 35 & 75 & 20 & 10,000 & +10 & +10 & GKT: 37 & GKT: 33 & GKT: 70 & $681,892.81$ & 0.23 \\
\hline & & & & & & & BET: 14 & BET: 5 & BET: 17 & & \\
\hline & & & & & & & AIT: 24 & AIT: 4 & AIT: 28 & & \\
\hline & & & & & & & Total: 75 & Total: 42 & Total: 125 & & \\
\hline \multirow[t]{4}{*}{18} & 35 & 75 & 20 & 10,000 & +20 & +20 & GKT: 37 & GKT: 33 & GKT: 70 & $1,117,491.31$ & 0.38 \\
\hline & & & & & & & BET: 14 & BET: 3 & BET: 17 & & \\
\hline & & & & & & & AIT: 24 & AIT: 4 & AIT: 28 & & \\
\hline & & & & & & & Total: 75 & Total: 40 & Total: 115 & & \\
\hline \multirow[t]{4}{*}{19} & 35 & 75 & 20 & 11,000 & +0 & +0 & GKT: 37 & GKT: 33 & GKT: 70 & $-20,857.42$ & -0.07 \\
\hline & & & & & & & BET: 14 & BET: 3 & BET: 17 & & \\
\hline & & & & & & & AIT: 24 & AIT: 4 & AIT: 28 & & \\
\hline & & & & & & & Total: 75 & Total: 40 & Total: 115 & & \\
\hline
\end{tabular}


Table 7 (continued)

\begin{tabular}{|c|c|c|c|c|c|c|c|c|c|c|c|}
\hline \multirow[t]{2}{*}{ SN } & \multicolumn{3}{|c|}{ MNF } & \multirow[t]{2}{*}{ LQW } & \multirow[t]{2}{*}{ LTU (\%) } & \multirow[t]{2}{*}{ LBE (\%) } & \multicolumn{3}{|l|}{ Facilities } & \multirow[t]{2}{*}{ OFV difference $(\$)$} & \multirow[t]{2}{*}{$\mathrm{D} \%$} \\
\hline & AIT & GKT & BET & & & & NCF & NNF & NTF & & \\
\hline \multirow[t]{4}{*}{20} & 35 & 75 & 20 & 11,000 & +10 & +10 & GKT: 37 & GKT: 33 & GKT: 70 & $-739,800.92$ & -0.25 \\
\hline & & & & & & & BET: 14 & BET: 4 & BET: 18 & & \\
\hline & & & & & & & AIT: 24 & AIT: 4 & AIT: 28 & & \\
\hline & & & & & & & Total: 75 & Total: 41 & Total: 116 & & \\
\hline \multirow[t]{4}{*}{21} & 35 & 75 & 20 & 11,000 & +20 & +20 & GKT: 37 & GKT: 32 & GKT: 69 & $1,115,904.11$ & 0.38 \\
\hline & & & & & & & BET: 14 & BET: 3 & BET: 17 & & \\
\hline & & & & & & & AIT: 24 & AIT: 4 & AIT: 28 & & \\
\hline & & & & & & & Total: 75 & Total: 39 & Total: 114 & & \\
\hline \multirow[t]{4}{*}{22} & 30 & 65 & 18 & 10,000 & +0 & +0 & GKT: 37 & GKT: 28 & GKT: 65 & $-2,981,128.97$ & -1 \\
\hline & & & & & & & BET: 14 & BET: 3 & BET: 17 & & \\
\hline & & & & & & & AIT: 24 & AIT: 4 & AIT: 28 & & \\
\hline & & & & & & & Total: 75 & Total: 35 & Total: 110 & & \\
\hline \multirow[t]{4}{*}{23} & 30 & 65 & 18 & 10,000 & +10 & +20 & GKT: 37 & GKT: 28 & GKT: 65 & $-2,258,178.26$ & -0.76 \\
\hline & & & & & & & BET: 14 & BET: 3 & BET: 17 & & \\
\hline & & & & & & & AIT: 24 & AIT: 4 & AIT: 28 & & \\
\hline & & & & & & & Total: 75 & Total: 35 & Total: 110 & & \\
\hline \multirow[t]{4}{*}{24} & 30 & 65 & 18 & 10,000 & +20 & +20 & GKT: 37 & GKT: 28 & GKT: 65 & $-1,894,740.62$ & -0.64 \\
\hline & & & & & & & BET: 14 & BET: 3 & BET: 17 & & \\
\hline & & & & & & & AIT: 24 & AIT: 4 & Ііт: 28 & & \\
\hline & & & & & & & Total: 75 & Total: 35 & Total: 110 & & \\
\hline \multirow[t]{4}{*}{25} & 30 & 65 & 18 & 11,000 & +0 & +0 & GKT: 37 & GKT: 28 & GKT: 65 & $-2,982,628.53$ & -1 \\
\hline & & & & & & & BET: 14 & BET: 3 & BET: 17 & & \\
\hline & & & & & & & AIT: 24 & AIT: 4 & AIT: 28 & & \\
\hline & & & & & & & Total: 75 & Total: 35 & Total: 110 & & \\
\hline \multirow[t]{4}{*}{26} & 30 & 65 & 18 & 11,000 & +10 & +10 & GKT: 37 & GKT: 28 & GKT: 65 & $-2,261,395.98$ & -0.76 \\
\hline & & & & & & & BET: 14 & BET: 3 & BET: 17 & & \\
\hline & & & & & & & AIT: 24 & AIT: 4 & AIT: 28 & & \\
\hline & & & & & & & Total: 75 & Total: 35 & Total: 110 & & \\
\hline \multirow[t]{4}{*}{27} & 30 & 65 & 18 & 11,000 & +20 & +20 & GKT: 37 & GKT: 28 & GKT: 65 & $-1,805,344.34$ & -0.61 \\
\hline & & & & & & & BET: 14 & BET: 3 & BET: 17 & & \\
\hline & & & & & & & AIT: 24 & AIT: 4 & AIT: 28 & & \\
\hline & & & & & & & Total: 75 & Total: 35 & Total: 110 & & \\
\hline
\end{tabular}

MNF maximum number of facilities which are allowed to be opened, EDAM the least quantity of waste needed to open a facility, LTU lower bound variation for transportation undesirable effect, $L B E$ lower bound variation for equity, NCF number of current facilities, NNF number of new facilities, NTF number of total facilities, OFV objective function value, D Difference, GKT Recycling Facility, BET disposal facility, AIT waste treatment facility

However, considering the amount of hazardous wastes generated and assuming that the facility capacities are as high as the capacity as was mentioned, 22 new facilities with $\mathrm{R} 5$ recycling technology are required. In other words, there are a large number of hazardous wastes needed to be treated by 22 facilities having $\mathrm{R} 5$ recycling technology, or these wastes are treated in unregistered facilities by unregistered methods.

The hazardous waste facility location and routing problem are an NP-hard class problem. For this reason, the solution is also difficult with the increasing complexity and the dimension of the problem. In the proposed model, the main focus is based on modelling facility location, facility types, technology-waste compatibility, risk and equity, to keep the problem dimension at an applicable and solvable level. Notice that the routing is not considered in the model. Problems involving more nodes require longer time to solve. For the future, it is recommended to use/develop heuristic solution methods that produce the close results to the best solution for problems which have more hazardous waste types with more nodes. 
In the developed model, the risk and equity constraints involve the population and the amount of waste transported or treated in the facilities. In the future studies, the models can be extended to the environmental impacts, including meteorological, geographical factors and regional flora in order to analyse the existing risk assessments. In the developed hazardous waste management model, we have considered only the highway transportation of hazardous wastes. The model can be developed by including different transportation modes.

\section{Compliance with ethical standards}

Conflict of interest The authors declare that they have no competing interests.

\section{References}

1. Alumur S, Kara BY (2007) A new model for the hazardous waste location routing problem. Comput Oper Res 34:1406-1423. https://doi.org/10.1016/j.cor.2005.06.012

2. The Republic of Turkey Ministry of Environment and Urbanization (2015) The waste management regulation (Atık Yönetimi Yönetmeliği), Resmi Gazete Tarihi: 02.04.2015, Resmi Gazete Sayısı: 29314

3. Emek E, Kara BY (2007) Hazardous waste management problem: the case for incineration. Comput Oper Res 34:14241441. https://doi.org/10.1016/j.cor.2005.06.011

4. Gionnikos I (1998) A multiobjective programming model for locating treatment sites and routing hazardous wastes. Eur J Oper Res 104:333-342. https://doi.org/10.1016/S0377 -2217(97)00188-4

5. Revelle C, Cohon J, Shobrys D (1991) Simultaneous siting and routing in the disposal of hazardous wastes. Transp Sci 25:99174. https://doi.org/10.1287/trsc.25.2.138

6. Samanlioğlu F (2013) A multi-objective model for the industrial hazardous waste location-routing problem. Eur J Oper Res 226:332-340. https://doi.org/10.1016/j.ejor.2012.11.019

7. Glickman TS, Erkut E, Zschocke MS (2007) The cost and risk impacts of rerouting railroad shipments of hazardous materials. Accid Anal Prev 39:1015-1025. https://doi.org/10.1016/j. aap.2007.01.006

8. Liu X, Saat MR, Barkan CPL (2013) Integrated risk reduction framework to improve railway hazardous materials transportation safety. J Hazard Mater 260:131-140. https://doi. org/10.1016/j.jhazmat.2013.04.052

9. Saat MR, Werth CJ, Shaeffer D, Hongkyu Y, Barkan CPL (2014) Environmental risk analysis of hazardous material rail transportation. J Hazard Mater 264:560-569. https://doi.org/10.1016/j. jhazmat.2013.10.051

10. Erkut E, Verter V (1995) Hazardous materials logistics. In: Drezner Zvi (ed) Facility location: a survey of applications and methods. Springer, Berlin, pp 467-506

11. Erkut $E$ (1993) Inequality measures for location problems. Locat Sci 1:199-217
12. Mandell MB (1991) Modeling effectiveness-equity tradeoffs in public service delivery systems. Manage Sci 37:467-482. https ://doi.org/10.1287/mnsc.37.4.467

13. Romero N, Nozick NK, Xu N (2016) Hazmat facility location and routing analysis with explicit consideration of equity using the Gini coefficient. Transp Res Part E Logist Transp Rev 89:165-181. https://doi.org/10.1016/j.tre.2016.02.008

14. Kang Y, Batta R, Kwon C (2014) Generalized route planning model for hazardous material transportation with VaR and equity considerations. Comput Oper Res 43:237-247. https:// doi.org/10.1016/j.cor.2013.09.015

15. Garrido RA, Bronfman AC (2017) Equity and social acceptability in multiple hazardous materials routing urban areas. Transp Res Part A Policy Pract 102:244-260. https://doi.org/10.1016/j. tra.2016.05.018

16. Zografos KG, Samara S (1989) A combined location-routing model for hazardous waste transportation and disposal. Transp Res Rec 1245:52-59

17. Stowers CL, Palekar US (1993) Location models with routing considerations for a single obnoxious facility. Transp Sci 27:313-400. https://doi.org/10.1287/trsc.27.4.350

18. List $G$ (1993) Siting emergency response teams: tradeoffs among response time, risk, risk equity and cost. In: Moses $L$, Lindstrom $D$ (eds) Transportation of hazardous materials. Kluwer Academic Publishers, Boston, pp 117-134

19. Cappanera P, Gallo G, Maffioli F (2004) Discrete facility location and routing of obnoxious activities. Discrete Appl Math 133:328. https://doi.org/10.1016/S0166-218X(03)00431-1

20. Boffey TB, Mesa JA, Ortega FA, Rodrigues JI (2008) Locating a low-level waste disposal site. Comput Oper Res 35:701-716. https://doi.org/10.1016/j.cor.2006.05.005

21. Erkut E, Karagiannidis A, Perkoulidis G, Tjandra SA (2008) A multicriteria facility location model for municipal solid waste management in North Greece. Eur J Oper Res 187:1402-1421. https://doi.org/10.1016/j.ejor.2006.09.021

22. Jiang $Y$, Zhang $X$, Rong $Y$, Zhang Z (2014) A multimodel location and routing model for hazardous materials transportation based on multi-commodity flow model. Procedia Soc Behav Sci 138:791-799. https://doi.org/10.1016/j.sbspro.2014.07.262

23. Meiyi W, Xiang L, Lean Y (2015) Time-dependent fuzzy random location-scheduling programming for hazardous materials transportation. Transp Res Part C Emerg Technol 57:146-165. https://doi.org/10.1016/j.trc.2015.06.012

24. Zhao J, Verter V (2015) A bi-objective model for the used oil location-routing problem. Comput Oper Res 62:157-168. https://doi.org/10.1016/j.cor.2014.10.016

25. Zhao J, Huang L, Lee DH, Peng Q (2016) Improved approaches to the network design problem in regional hazardous waste management systems. Transp Res Part E Logist Transp Rev 88:52-72. https://doi.org/10.1016/j.tre.2016.02.002

26. Yılmaz Ö, Kara BY, Yetiş Ü (2017) Hazardous waste management system design under population and environmental impact considerations. J Environ Manage 203:720-731. https ://doi.org/10.1016/j.jenvman.2016.06.015

27. Rabbani M, Heidari R, Farrokhi-AsI H, Rahimi N (2018) Using metaheuristic algorithms to solve a multi-objective industrial hazardous waste location-routing problem considering incompatible waste types. J Clean Prod 170:227-241. https:// doi.org/10.1016/j.jclepro.2017.09.029

28. Rabbani M, Heidari R, Yazdanparast R (2019) A stochastic multi-period industrial hazardous waste location-routing problem: integrating NSGA-II and Monte Carlo simulation. Eur J Oper Res 272:945-961. https://doi.org/10.1016/j. ejor.2018.07.024 
29. Karadag AA (2018) A profit oriented hazardous waste locating-routing problem. J Clean Prod 202:213-225. https://doi. org/10.1016/j.jclepro.2018.08.106

30. Zhao J, Ke GY (2017) Incorporating inventory risks in locationrouting models for explosive waste management. Int J Prod Econ 193:123-136. https://doi.org/10.1016/j.ijpe.2017.07.001

31. List G, Mirchandani PB (1991) An integrated network/planar multiobjective model for routing and siting for hazardous materials and wastes. Transp Sci 25:146-156. https://doi.org/10.1287/ trsc.25.2.146

32. Current J, Ratick S (1995) A model to assess risk, equity and efficiency in facility location and transportation of hazardous materials. Locat Sci 3:187-201. https://doi.org/10.1016/09668349(95)00013-5

33. Wyman MM, Kuby M (1995) Proactive optimization of toxic waste transportation, location and technology. Locat Sci 3:167185. https://doi.org/10.1016/0966-8349(95)00014-3

34. Alidi SA (1996) A multiobjective optimization model fort the waste management of the petrochemical industry. Appl Math Model 20:925-933. https://doi.org/10.1016/S0307 $-904 X(96) 00106-0$

35. Nema AK, Modak PM (1998) A strategic design approach for optimization of regional hazardous waste management systems. Waste Manage Res 16:210-224. https://doi.org/10.1177/07342 42X9801600303

36. Nema AK, Gupta SK (1999) Optimization of regional hazardous waste management systems: an improved formulation. Waste Manag 19:441-451. https://doi.org/10.1016/S0956 -053X(99)00241-X

37. Nema AK, Gupta SK (2003) Multiobjective risk analysis and optimization of regional hazardous waste management system. Pract Period Hazard Toxic Radioact Waste Manag 7:69-77. https ://doi.org/10.1061/(ASCE)1090-025X(2003)7:2(69)

38. Republic of Turkey Ministry of Environment and Urbanization-General Directorate of Environment Management (2014) Sanitary facilities field administration and management guide. http://www.webcitation.org/query?url=https \%3A\%2F\%2Fwww.csb.gov.tr\%2Fdb\%2Fdestek\%2Feditordo sya\%2FDuzenli_Depolama_Tesis_Saha_Yon_ve_isletme_kilav uzu.pdf\&date=2016-11-24. Accessed 24 Nov 2016

39. Republic of Turkey Ministry of Environment and Urbanization (2014) Hazardous waste statistics. http://www.webcitation.org/ query?url=http $\% 3 \mathrm{~A} \% 2 \mathrm{~F} \% 2 \mathrm{Fwww} . \mathrm{csb} . g o v . t r \% 2 \mathrm{Fdb} \% 2 \mathrm{Fced}$ \%2Feditordosya\%2F2014_YILI_TEHLIKELI_ATIK ISTATISTIK LERI_15022016.pdf\&date=2016-11-24. Accessed 24 Nov 2016

40. Republic of Turkey Ministry of Environment and Urbanization (2016) Data gathering recording. Number: 39463277-145.01E.5618, Issue: Data Request. Date: 4 April 2016, 17:55

41. Gaziantep Chamber of Industry (2012) Prefeasibility report. http://www.webcitation.org/query?url=http\%3A\%2F\%2Fwww .ika.org.tr\%2Fupload\%2Fyazilar\%2F2011-DFD-Raporlari-18873 7.pdf\&date=2016-11-24. Accessed 24 Nov 2016
42. IZAYDAŞ Annual Activity Report (2015) http://www.webcitatio n.org/query?url=https\%3A\%2F\%2Fwww.izaydas.com.tr\%2Ffil es\%2Fdocuments\%2Fizmit_atik_ve_artiklari-aritma-yakma _ve_degerlendirme-2015_yillik_faaliyet_raporu9_4_2016_1431-43.pdf\&date=2016-11-24. Accessed 24 Nov 2016

43. AKÇANSA (2015) http://www.webcitation.org/query ?url=http\%3A\%2F\%2FURL\%3A+http\%3A\%2F\%2Fwww.akcan sa.com.tr\&date $=2016-11-24$. Accessed 24 Nov 2016

44. AKÇANSA Annual Activity Report (2015) http://www.webci tation.org/query?url=http\%3A\%2F\%2Fwww.akcansa.com. tr\%2F+docs $\% 2 F+f a a l i y e t 2015 . p d f \& d a t e=2016-11-24$. Accessed 24 Nov 2016

45. Enerji Atlasi (2016) http://www.webcitation.org/query ?url=http\%3A\%2F\%2FURL\%3Ahttp\%3A\%2F\%2Fwww.enerjiatla si.com\%2Felektrik-fiyatlari\%2F\&date=2016-11-24. Accessed 24 Nov 2016

46. Central Bank of the Republic of Turkey (2016) http://www. webcitation.org/query?url=http\%3A\%2F\%2Fwww.tcmb.gov. tr\%2Fkurlar\%2F200904\%2FApr_tr.html\&date=2016-11-24. Accessed 24 Nov 2016

47. Tire Recycling Facility (2016) http://www.webcitation.org/ query?url=http $\% 3 \mathrm{~A} \% 2 \mathrm{~F} \% 2 \mathrm{Fwww}$.bedriagac.org\%2Find ex.php\%2Fcomponent $\% 2$ Fcontent $\% 2$ Farticle $\% 2 \mathrm{~F} 2$-proje lerim \%2F49-35-lastik-geri-doenueuem-tesisi\%3Fphp MyAdmin\%3Dc534def7fa5a8b3a3fa41 ef261fddef4\%26php MyAdmin\%3DAsTAy\%252C0AMATrDeQDol9\%252CnSsO77 c\&date $=2016-11-24$. Accessed 24 Nov 2016

48. Out of Use Waste Oil Recycling (2015) http://www.webcitatio n.org/query? url=http\%3A\%2F\%2Fwww.bedriagac.org\%2Find ex.php\%2Fcevreciprojeler\%2Fkullanim-dii-kalan-atik-maden -yalarin-ger-doenueuemu\&date=2016-11-24e. Accessed 24 Nov 2016

49. Central Bank of the Republic of Turkey (2016) http://www. webcitation.org/query?url=http\%3A\%2F\%2Fwww.tcmb.gov. tr\%2Fkurlar\%2Ftoday.xml\&date=2016-11-24. Accessed 24 Nov 2016

50. Investment and Operating Costs for Waste Management Systems and Purification Prices for Different Waste Types (2007) Life Hawaman Project Life 06 TCY TR/000292. http://www.webci tation.org/query?url=http $\% 3 \mathrm{~A} \% 2 \mathrm{~F} \% 2$ Fatanafs.com $\% 2$ Fima ges\%2Fstories\%2Fdownload\%2FAtik_Yonetim_Sistemleri_icin Yatirim_ve_sletim_Maliyetleri_ve_Cesitli_Atik_Turleri_icin_Ariti m_Fiyatlari.pdf.pdf\&date=2016-11-24. Accessed 24 Nov 2016

51. Revenue Administration (2016) Amortization rates. http:// www.webcitation.org/query?url=http $\% 3 \mathrm{~A} \% 2 \mathrm{~F} \% 2 \mathrm{Fwww}$ .gib.gov.tr\%2Fsites\%2Fdefault\%2Ffiles\%2Ffileadmin\%2Fuse r_upload\%2FYararli_Bilgiler\%2Famortisman_oranlari. pdf\&date=2016-11-24. Accessed 24 Nov 2016

Publisher's Note Springer Nature remains neutral with regard to jurisdictional claims in published maps and institutional affiliations. 